\begin{tabular}{|c|c|c|}
\hline Received 08.12.2021 & \multirow{3}{*}{ Research Article } & \multirow{3}{*}{$\begin{array}{c}\text { JOTS } \\
6 / 1 \\
\text { 2022: } 118-134\end{array}$} \\
\hline Accepted 19.12.2021 & & \\
\hline " Published 01.01.2022 & & \\
\hline
\end{tabular}

\title{
Hun Siyasî Sisteminde Akrabalık
}

\author{
Kinship in the Xiongnu Political System
}

\author{
Erhan TAŞBA Ş* \\ National Chengchi University (Taipei/Tayvan) \\ E-mail: ertasbas@gmail.com
}

This paper aims to examine the social bases of the hierarchical political organization based on kinship, which is typical with the Xiongnu (Asian Hun) and their successors, and the basic concepts that express it in the context of the cultural continuum. The study also analyzes the role of kinship diplomacy within the political culture of Xiongnu with historical instances and concludes that despite some exceptions, Xiongnu had developed an institutionalized political hierarchy based on kinship relations.

Key Words: Xiongnu, Asian Huns, kinship, kinship diplomacy, political system.

ORCID ID: 0000-0003-2107-7931. 


\section{ग(ब)}

\section{Giriş}

Akrabalık, karmaşık terminoloji ve evlilik kurallarından oluşan mantıksal bir yapı olmanın ötesinde, politik örgütlenmenin temel dayanaklarından biri, dünyayı kavramanın ve düzenlemenin bir yoludur (Lindholm, 1986: 337). Diğer İç Asya göçebe halkları gibi Hunlar da soy birliğine ve akrabalık ilişkilerine dayalı bir örgütlenme biçimi uygulamışlardır. Günümüzde Orta Asya ve İç Asya'nın bazı bölgelerinde varlığını sürdüren bu örgütlenme biçimi ortak bir ataya sahip akraba grupların ilişkisine dayanmaktadır. İzleri günümüzdeki bazı Türk halklarında ve Moğollarda hâlâ yaşayan bu sosyal yapıda aileler urukları (klanları), uruklar boyları, boylar da daha büyük boy birliklerini oluşturmakta ${ }^{1}$, tüm bu soy grupları ise onları siyasî olarak bir arada tutan bir yönetici boy ve onun evlilik yoluyla ittifak kurduğu diğer boylar tarafından yönetilmektedir. Bu yönetim biçiminde askerî ve idarî kontrol ortak soya dayanan organik bir sosyal grup içinde birleşmektedir (Liao, 2004: 1).

Hunlarda akrabalık örgütlenmesi diğer soy gruplarıyla kurulan ilişkileri de kapsamaktadır. Evlilik kurumuyla özdeşleşen bu ilişkiler Hun toplumunda farklı soy grupları arasındaki aktif ilişkinin temel dayanaklarından biridir. Hunlarda aynı soy grubundan kadın ve erkeklerin birbirleriyle evlenmelerine izin vermeyen ve eşlerini başka bir soy grubundan bulunmasını şart koşan bir evlilik sistemi yerleşmiş olduğu için evlilik bağı yalnızca bireyler arasında değil, aynı zamanda farklı boy ve uruklar (klanlar) arasında kurulmuştur (Lin, 1986: 176). Tarihi olarak ilk kez Çin kaynaklarında kaydedilen bu kültüre dair bilgiler arkeoloji ve genetik alanındaki yeni verilerle de uyuşmaktadır. Güney Sibirya'da ortaya çıkarılan mezar kalıntılarında erkek kardeş, ebeveyn ve onların reşit olmayan çocuklarının aynı mezar kompleksine, buna karşlık yetişkin kız kardeşlerin ayrı mezarlara gömüldüğünü gösteren bulgular (Mary vd., 2019: 421), Hunlardan sonra da yüzyllarca İç Asya ve Orta Asya'da uygulanan boy/soy egzogamisinin sürekliliğini ortaya koymaktadır.

Akrabalık bağına sahip grupların meydana getirdiği Hun toplumunun siyasî sistemi de birçok yönden sonraki göçebe toplumlarla benzer özellikler

Çalı̧mada yararlanılan Çin kaynaklarında 'aile', 'klan', 'boy', 'soy' gibi anlamlara gelen shì 氏, xing 姓 ve zú 族 terimlerinin kullanımında bir birlik bulunmadığı için uruk (klan) ile diğer soy grupları (aile, boy vb.) arasındaki ayrım çoğu zaman belirsizdir. Bu nedenle çalışmada boy terimi 'uruk' anlamında da kullanılmıştır. 


\section{ग(ब)}

sergilemektedir (Taskin, 1973: 17). Bu gruplar arasındaki uyum, ittifak ve güç mücadeleleri birliğin yönetici sınıfını belirlediği için Hun siyasî sistemi ile aile ve akrabalık yapısını birlikte anlamak gerekmektedir.

\section{Kayın Boylar ve Akrabalık Diplomasisi}

Hun konfederasyonunda hükümdar (çanyü) ve ailesinin mensup olduğu boy sosyal hiyerarşinin en üstünde yer almakta, devlet örgütlenmesi de bu boy etrafında şekillenmektedir. Hunların ardılı olan halkların da devam ettirdiği bu bozkır göçebe geleneğinde, en yüksek idari ve askerî mevkilerin hükümdar ailesi için kalıcı hâle gelmesi bu ailenin mensup olduğu boyun da diğer boylar arasında yükselmesine neden olmaktadır (Harmatta, 1952: 296). Göktürklerde Aşina, Uygurlarda Yaglakar, Moğollarda Borcigin adlarıyla bilinen kurucu-yönetici boylar bozkır devlet örgütlenmesinin çekirdeğini oluşturmakta, bir hanedan darbesi olmadığı sürece hükümdarlar bu boya mensup bir aileden seçilmektedir. Hunlarda çanyülerin seçildiği bu yönetici boyun adı Çin tarih kitaplarından Hanshu'da Luandi, Hou Hanshu'da Xulianti olarak kaydedilmiştir. Bu iki etnonim aynı Hun sözcügünün farklı dönemlerdeki farklı Çince söyleniş biçimleri olmalıdır (Miller, 2014: 5).

Lindholm (1986: 340) akrabalık temelli devlet örgütlenmesinin imparatorluk öncesi döneme özgü olduğunu, yönetim merkezileşip karmaşıklaştıkça ve soy dışından kimseler devlet yönetiminde etkin olmaya başladıkça akrabalığın rolünün azaldığını belirtmektedir. Bu tespit yönetici sinıfta tek soy'a dayalı örgütlenme modelinin zamanla ortadan kalkması hususunda açıklayıcıdır. Bununla birlikte yönetici sınıfa farklı soy gruplarından katılım olması genellikle akrabalık ağının evlilik ittifakları yoluyla genişletilmesi nedeniyle gerçekleşmiştir. Bu da akrabalığa dayalı örgütlenme biçiminin terk edildiğini değil, yeniden yorumlanarak siyasî sisteme uydurulduğunu göstermektedir. Bozkır imparatorluklarında devlet örgütünün ve hâkimiyet altına alınan toprakların genişlemesiyle birlikte yönetici sınıfın kurucu boy dışından ittifaklara ihtiyaç duymaya başladığı görülmektedir. Çanyünün boyu ile diğer boylar (kayın boylar) arasındaki ittifak evlilik yoluyla kurulmuştur. Kayın boylar çanyünün mensup olduğu yönetici boyun en yakın müttefikleri oldukları gibi Hun aristokrasisinde Luandi boyundan sonra gelmişlerdir. Bununla birlikte bu boylar arasında da önem ve kıdem bakımından farklılık söz konusudur. İç 
siyasetteki dinamiklere göre devlet hiyerarşisinde bir boy diğerlerinden daha aşağı veya daha yukarı konumda olmuştur (Miller, 2014: 5):

1. a. 其大臣皆世官呼衍氏蘭氏

Yüksek makamlar kuşaktan kuşağa Huyan ve Lan ailelerinin üyeleri tarafından doldurulur (Shiji 110.3495).

b. 呼衍氏, 蘭氏, 其後有須卜氏, 此三姓, 其貴種也

Huyan ailesi (soyu), Lan ailesi ve daha sonra Xubu ailesi; üçü de soylu boylardır (Hanshu 94a.3751).

c. 異姓有呼衍氏、須卜氏、丘林氏、蘭氏四姓, 為國中名族, 常與單于婚姻。呼衍氏 為左, 蘭氏、須卜氏為右

Diğer soylu boylar Huyan, Xubu, Qiulin ve Lan boylarıdır. Bunlar ülkede tanınmış boylardır ve genellikle çanyü ile evlidirler. Huyan sol kanatta, Lan ve Xubu sağ kanattadır (Hou Hanshu 89.2944-2945).

İttifak evlilikleri değişen sosyal, ekonomik veya siyasî koşullarla doğrudan ilişkili olduğu için bu boylara yenilerinin eklenmesi de olağandır. Nitekim kayın boylar hakkındaki ilk bilgilerin dayandığı Han hanedanlık tarihlerinden (Shiji, Hanshu, Hou Hanshu) alınan yukarıdaki kayıtlardan ilk ikisinde üç farklı boydan bahsedilirken üçüncü kayıtta dört yönetici boyun adı geçmektedir. Bu görüntü Hun siyasî birliği içindeki birtakım değişikliklerin yansıması olarak kabul edilebilir. Buna göre önceleri evliliklerini yalnızca iki boydan (Huyan ve Lan) kadınlarla gerçekleştiren çanyü, daha sonra birlik içinde güç kazanan boylarla da evlilik ittifakı kurmuş olmalıdır. Ayrıca üçüncü kayıtta Huyan boyunun sol kanatta yer alması bu boyun diğerleri arasında daha ayrıcalıklı olduğunu göstermektedir. $\mathrm{Bu}$ ayrıcalık çanyülerin ilk eşini bu boydan seçmesinden kaynaklanmaktadır. Aşina boyuna mensup Göktürk kağanlarının eşlerini Aşide boyundan seçmesi, bu boya mensup olan Bilge Tunyukuk'un Bilge Kağan'ın hem kayınbabası hem de başveziri olması Hunlardaki kayın boy geleneğinin İç Asya bozkır devlet geleneğindeki sürekliliğine işaret etmektedir. Benzer biçimde Çingis Kağan'ın annesinin ve ilk eşinin Moğol Hongirad (Moğolca Хонгирад) boyundan olması (Onon, 2001: 58-60) bu bağlamda değerlendirilebilecek örneklerdendir.

Luandi boyu ve kayın boyların (Huyan, Lan, Xubu) oluşturduğu yönetici sınıf kaynaklarda sijiao ‘dört boynuz' ve liujiao 'altı boynuz' olarak adlandırılmaktadır. Bunlardan ilki çanyünün oğlu ve erkek kardeşlerinden, ikincisi ise Luandi 
boyuna ve onlarla evlilik yoluyla bağ kuran yukarıdaki boylara mensup yöneticilerden oluşmuştur (Kim, 2017: 18-22). Bu yönetim sisteminde çanyünün oğulları, amcaları ve erkek kardeşlerinin yanı sıra dayıları, kayınbiraderleri ve kayınbabaları da önemli mevkilere gelmektedir (Xie, 1969: 686). Boylar arasındaki evlilik bağı kuşaklar boyunca devam ettiği için anne tarafından akrabaların ve kayın boyların devlet yönetiminde kalıcı bir etkisi söz konusudur.

Hun üst yönetiminin en geniş biçimiyle "çanyü boyu" ve "kayın boylar"dan oluşması (Ögel, 1982: 344; Xie, 1969: 675) zamanla hâkimiyet alanı büyüyen devletin akrabalık temelli örgütlenme modelini ülkenin uzak bölgelerinde de uygulama ihtiyacından kaynaklanmıştır. Bu bağlamda evlilik anlaşmaları yalnızca idarî hiyerarşinin pekiştirilmesinde değil, ülke sınırlarının genişletilmesinde de önemli rol oynamıştır. Hunlarda tipikleşip İç Asya'nın sonraki göçebe halklarına da miras kalan bu gelenek farklı dönemlerde çeşitli şekillerde uygulanmaya devam etmiştir. Örneğin, Çingis Kağan geleneksel evlilik anlaşmasını komşu ülkeler üzerindeki egemenliğini kalıcılaştırmak için kullanmıştır. Çingis Kağan'ın zorlamasıyla uzun süreli savaşlara katılan kocalarının yerine vekâlet eden eşleri (Çingis Kağan'ın kızları), kocaları bu savaşlardan sağ dönemediğinde bulundukları ülkelerin yöneticisi hâline gelip babalarının komşu ülkeler üzerindeki etkisini pekiştirmişlerdir (Lkhagvasuren vd., 2016: 2).

Evlilik anlaşmaları iç politikada olduğu kadar dış politikada da bozkır siyaseti açısından önemli yere sahiptir. Çin'deki Zhou kralının göçebe Di halkından olan eşini kraliçelikten indirmesi sonucu Di ordusunun Çin başkentine saldırması (Durrant \& Schaberg, 2016: 284-385), evlilik talebinin reddedilmesi üzerine Göktürklerin Rouran başkentine saldırması ve ittifak kurmak amacıyla Xiwei 'Kuzey Wei' hanedanlığına aynı teklifi götürmesi (Linghu, 1971: 908), Çin imparatorunun ittifak için Batı Göktürklerine bir prenses göndermek istemesi ve Doğu Göktürk kağanının bu anlaşmayı engelleme çabaları (Jiu Tangshu 194B.5181-5182), Çin'in On Altı Krallk Dönemi'nde (MS. 304-439) Hun soyundan gelen Liu Yuan'in geçmişte Hun ve Çin hükümdarları arasındaki evlilik anlaşmalarına dayanarak Çin tahtında hak iddia etmesi (Jinshu 101.2644-2645) gibi örnekler evlilik yoluyla kurulan akrabalıkların iktidar ilişkileri üzerindeki etkisi açısından dikkate değerdir. Özellikle MÖ. 200'deki Baideng savaşının ardından Han imparatorunun Hun çanyüsü Modu ile anlaşarak başlattığı heqin 


\section{ग(৫)}

'evlilik yoluyla barış' politikası Hunlar (daha sonra Göktürk ve Moğol kağanlıkları) ile Çin arasında yüzyıllarca devam edecek olan politik evliliklerin başlangıcı olmuştur. İki hükümdarın evlilik yoluyla sürdürdüğü heqin uygulaması Bozkır ve Çin arasındaki ilişkileri farklı bir düzeye taşımış, İç Asya devletleri arasında akrabalık diplomasisinin gelişmesini sağlamıştır.

Bozkır göçebe toplumlarında kan ve evlilik bağına dayalı akrabalık devlet yönetiminde her zaman işlevsellik taşımıştır. Hem Hunlarda hem de sonraki bozkır devletlerinde kan bağına dayalı akrabalık daha çok hanedanın kimliği ve devamlılığıyla özdeşleşirken evlilik anlaşmalarıyla kurulan akrabalık devletin etki alanını genişletme amacına hizmet edecek biçimde Hun siyasetinde kurumsallaşmıştır.

\section{Kıdemli Kayın Boylar ve Baş Eş}

Hun toplumu boy ve uruk liderleri tarafından yönetildiği için yalnızca yönetici sınıf değil, daha alt sosyal ve askerî sınıflar da dâhil olmak üzere tüm toplumsal gruplar akrabalık temelinde örgütlenmiştir. Bu sistemde askerî, adli ve mali hiyerarşinin başında boy-uruk liderleri ve "yaşça en büyük" kişiler yer almıştır (Kradin, 2011: 89). Bu anlayış yönetici aile de dâhil olmak üzere toplumun bütün sosyal gruplarına yansımıştır. Hanedan açısından bakıldığında çanyünün kayın boylardan seçtiği eşler arasında da bir hiyerarşi düzeni söz konusudur. Bu düzen bir sonraki çanyünün kim olacağıyla yakından ilgilidir. Kıdemli kayın boya mensup ilk eş tipik olarak "baş eş" unvanını almıştır. Hunlarda yanzhi adıyla bilinen hükümdar eşinin ilk oğlu tahtın doğal varisi durumundadır. $\mathrm{Bu}$ da baş eşin boyunu diğerlerinden daha önemli hâle getirmiştir. Çingis Kağan'ın Moğol Hongirad boyuna mensup annesinin ve ilk eşinin aynı zamanda baş eş olması (Onon, 2001: 58-60) Hunlardaki bu gelenekle bağlantılıdır.

Çanyülerin farklı boylara mensup birden fazla eşi olsa da tahtın varisi baş eşin çocuklarıdır (Kradin, 2011: 92). Aksi bir durum gerçekleşmedikçe baş eşin en büyük oğlu genellikle bir sonraki çanyü olmuştur. Hunlardan sonra diğer Türk ve Moğol bozkır devletlerinde de sürdürülen bu geleneğe aykırı ilk örnek Han

Türkler arasında hükümdar baş eşi için kullanılan katun (hatun) unvanının karşllığı Hunlarda yanzhi'dir. 
tarih kitaplarında, Hun çanyüsü Touman ile büyük oğlu Modu arasındaki iktidar savaşını anlatan bölümde kaydedilmiştir:

2. 單于有太子名冒頓。後有所愛閼氏, 生少子, 而單于欲廢冒頓而立少子, 乃使冒 頓質於月氏。冒頓既質於月氏，而頭曼急擊月氏。月氏欲殺冒頓

Çanyünün Modu adında bir veliaht prensi vardl. Daha sonra kendisine oğul veren bir yanzhi'ye bağlandı. Çanyü Modu'yu bertaraf edip küçük oğlunu onun yerine geçirmek istedi, Modu'yu Yuezhilere rehin olarak gönderdi. Modu rehinken Touman ansızın Yuezhilere saldırdı. Yuezhiler Modu'yu öldürmek istedi... (Shiji 110.3493).

Yukarıdaki kayıt Hunlar arasında görülen çok eşlilik, taht veraseti ve ekberiyet ilkesi gibi konularda dikkate değer bir referanstır. Bununla birlikte Touman'ın Modu'yu Yuezhilere rehin gönderme nedeni ve sonuçları üzerinde de durmak gerekmektedir. Bu kayıtta Modu'nun annesi olan ilk yanzhi hakkında bilgi bulunmaması Touman'ın ilk eşinin ölmüş olma olasıllğını güçlendirmektedir. Kaydın devamında anlatılanlar yukarıda bahsedilen olayın nedeninin Touman'ın eşine düşkünlüğünden ibaret olmadığını düşündürmektedir:

3. 從其父單于頭曼獵, 以鳴鏑射頭曼, 其左右亦皆隨鳴鏑而射殺單于頭曼, 遂盡誅 其後母與弟及大臣不聽從者。冒頓自立為單于

(Modu) babası Touman Çanyü'ye eşlik ettiği bir av sırasında ıslık çalan bir ok attı, sağ ve sol taraftan tüm takipçileri de oklarını aynı yöne doğrulttu ve çanyüyü vurdular. Sonra Modu üvey annesini, erkek kardeşini ve kendisinden emir almayı reddeden tüm yöneticileri idam ederek kendini çanyü ilan etti (Shiji 110.3493).

Hunlarda ve sonraki bozkır devletlerinde en büyük oğul aynı zamanda anne tarafından ilişkili olduğu kayın boyun da çanyü adayıdır. Bu bağlamda Touman'ın meşru veliahtı bertaraf etmeye çalışması kayın boylarla ilgili siyasette önemli bir değişikliğe işaret etmektedir. Modu'nun gözden çıarılması çanyü ile Modu'nun anne boyu arasındaki ilişkilerin bozulmasıyla açıklanabilir. Modu, üvey annesi ve erkek kardeşini öldürdükten sonra ülkenin bazı ileri gelenleri ona itaat etmemiştir. Bunlar üvey annesinin boyuna mensup veya onları destekleyen yöneticiler olabilir. Bu nedenle Modu'nun gerçekleştirdiği darbe yalnızca babasına değil, aynı zamanda onun oluşturmak istediği yeni yönetim hiyerarşisine karşıdır. Bu darbede Modu'nun emri altındaki askerlerden başka öz annesinin boyundan da destek aldığı varsayılabilir. Hun soylu sınıfının yeni boylarla genişleme siyasetinin yarattığı çatışma potansiyeli (Miller, 2014:13) gözönünde bulundurulduğunda kayın boylar arasında zaman zaman baş eş 


\section{J(৫)}

vasıtasıyla "kıdemli kayın boy" olmak için bir rekabetin oluştuğu düşünülebilir. Nitekim Hanshu'da geçen bir kayıt bu durumu örneklemektedir: MÖ 68 yılinda Hun çanyü'sü Huyandi öldüğünde onun yerine geçen kardeşi Xulüquanqu dul yengesi ile evlenmek yerine geleneği çiğneyerek başka soydan bir kadınla evlendiği için yengesinin "sol daqiequ" unvanlı babası bu duruma öfkelenmiştir (Hanshu 94A.3787; Lin, 1986: 178).

Kaynaklara göre Huyan boyu ülkenin sol kanadında yaşamaktadır (Hou Hanshu 89.2944-2945). Bu da onların "kayın boy hiyerarşisi”nin en üstünde yer aldıklarının göstergesidir. Bilindiği gibi Hunlarda devletin ve ordunun merkezi sol kanatta, yani ülkenin doğusundadır. Sol kanat gelenek olarak çanyünün büyük oğlu tarafından yönetilirken sağ kanat, yani ülkenin batısı çanyünün yakın akrabalarının idaresindedir (Ögel, 1982: 340). Bu bağlamda Huyan boyunun Hun devletinin kuruluşunda Luandi boyu ile ittifak yaptığı, zamanla kayın boylara diğerlerinin eklendiği anlaşılmaktadır. Nitekim Hanshu ve Hou Hanshu'daki kayıtlar (Hanshu 94A.3751; Hou Hanshu 89.2944) Xubu ile Qiulin boylarının sonradan Hun aristokrasisine katıldıklarını göstermektedir:

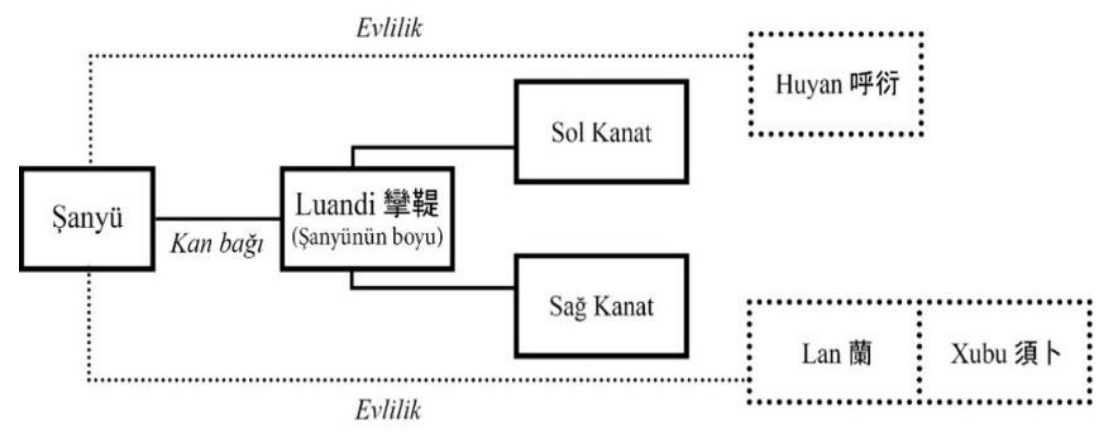

Diyagram I: Hun yönetici sınıfı ve kayın boylar

\section{Ekberiyet ve Ehliyet İlkesi}

Eski Türklerde olduğu gibi (Ecsedy, 1972: 250-251; Tishin, 2019: 119) Hunlarda da toplumun en küçük ekonomik birimi geniş ailedir (Xie, 1969: 702). Bu aile tipik olarak "baba"nın değil "dede"nin etrafında şekillenmektedir. Dedenin ölümü durumunda ise ailenin liderliği en büyük erkeğe (çoğu durumda babanın en büyük ağabeyine) geçmektedir (Taşbaş, 2019: 249). Bu sistemde kişinin amcası (genellikle büyük amcası) yapısal olarak babasına, erkek kardeşinin çocuğu da kendi çocuğuna eşdeğer kabul edilmektedir (Scheffler, 1980: 240). Söz konusu aile hiyerarşisi Hunların ve daha sonraki göçebe bozkır devletlerinin taht veraset geleneğinde uygulama alanı bulmuştur. Tahtın 


\section{ग(৫)}

babadan büyük oğula geçmesi en sık karşllaşılan uygulama olsa da büyük oğulun ehliyeti birçok durumda hükümdarın belirlenmesinde ihtilaf yaratmıştır. Bu gibi durumlarda ailenin en büyük erkeğinin, yani amcanın çanyü olduğu görülmektedir. Hunların ardılı olan Türk ve Moğol halklarının dillerinde 'küçük amca' ve 'ağabey' kavramlarının aynı terimle ifade edildiği (Eski Türkçe eçi, Orta Moğolca aga) (Clauson, 1972: 20; Dziebel, 2007: 238) göz önüne alınırsa Hunlarda da 'ailenin en büyük erkek üyesi' sıfatıyla küçük amcanın tahtta hak iddia etmesi olağandır. Ancak taht verasetine dair uygulamalar daha çok veliaht prensin ülke yönetme ehliyetinin tartışmalı olduğu durumlarda anlaşmazlık yaşandığını göstermektedir. Ehliyet ve yaş kavramlarının tartışmaya açık olması farklı dönemlerde çanyünün oğlu ile hanedanın diğer üyeleri arasında iktidar mücadelelerine neden olmuştur. Bu nedenle kaynaklar çanyü unvanının en büyük oğul, erkek kardeş, amca ya da yeğen arasındaki geçişliliğini kaydeden örnekler sunmaktadır:

4. a. 其後冬, 匈奴軍臣單于死, 其弟左谷蟙王伊稚斜自立為單于, 攻敗軍臣單于太子 於單。於單亡降漢

Tahtta bir kış geçirdikten sonra Xiongnu Junchen Çanyü öldü. Daha sonra küçük kardeşi “Sol Guli Bey" Yizhixie kendini çanyü atadı. Çanyü Junchen'in büyük oğlu Yudan'a saldırdı ve onu yendi. Yudan kaçarak Han'a (Çin'e) sığındı (Shiji 110.3512).

b. 兒單于立三歲而死。子少, 匈奴乃立其季父烏維單于弟右賢王句黎湖為單于

Er Çanyü üçüncü saltanat yılında öldü. Oğlu küçüktü, Xiongnular küçük amcayı, (yani) Wuwei’in kardeşi “Sağ Bilge Bey” Xulihu'yu çanyü olarak seçtiler (Shiji 110.3522).

c. 呴犁湖單于立一歲死。匈奴乃立其弟左大都尉且鞮侯為單于

Xulihu Çanyü bir yıl sonra öldü ve Hunlar kardeşi Sol Da Duwei (büyük komutan) Qiedihou'yu çanyü seçti (Shiji 110.3523).

Aşağıdaki diyagram Hunlarda ilk dört saltanat devresinin (Touman, Modu, Laoshang, Junchen) baba-oğul çizgisinde sürdürüldüğünü, sonraki dönemlerde zaman zaman veraset sırasının değiştiğini göstermektedir:

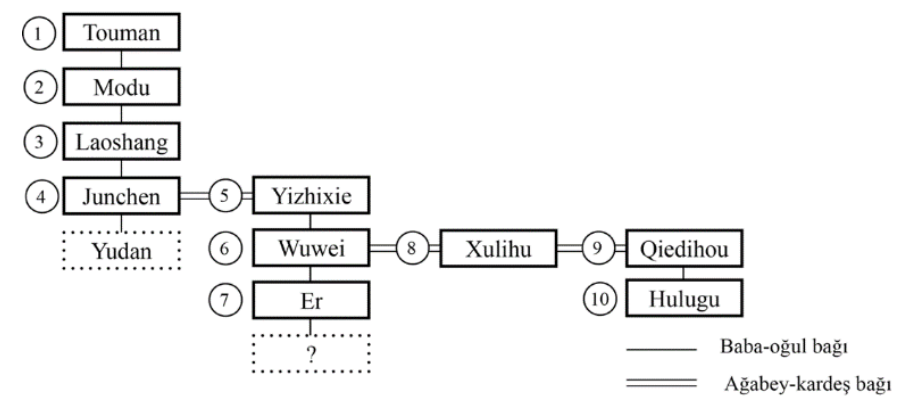

Diyagram II: Hunların ilk on çanyüsü 


\section{ग(৫)}

Ülke yönetiminin baş eșten olan ilk erkek çocuğa mı yoksa hanedanın en büyük üyesine mi geçeceği tartışması sonraki göçebe devletlerinde de söz konusu olmuştur. Göktürk Kağanlığı'nın kurucusu İlteriş'in ölümünün ardından tahta kardeşi Kapgan Kağan'ın geçtiği, o sırada İlteriş Kağan'ın en büyük oğlu Bilge'nin henüz sekiz yaşında olduğu bilinmektedir: Kangım kagan uçdukda özüm sekiz yaşda kaltım ol törüde üze eçim kagan olurtı "Babam kağan vefat ettiğinde ben sekiz yaşımda kaldım. O zamanki töreye göre amcam hakan olarak tahta oturdu" (Tekin, 1998: 66-67).

Moğol kağanı Çingis'in ilk iki oğlu (Cüçi ve Çagaday) arasındaki ihtilaf da bu bağlamda dikkate değerdir. Çingis Kağan'ın baş eşi Börte düğünlerinden kısa bir süre sonra Merkitler tarafından kaçırıldığı için Cüçi'nin gerçek babasının kim olduğu konusunda şüphe bulunmaktadır. Bu şüpheye dayanarak Çingis Kağan'ın ikinci oğlu Çagaday ağabeyi Cüçi'nin kağan olamayacağını savunduğu için Çingis Kağan meclis önünde tahtı üçüncü oğlu Ögedey'e bırakarak bu anlaşmazlığı çözme yoluna gitmiştir (Onon, 2001: 242-246). Bu örnekte ekberiyet ilkesinin uygulanmama nedeni iki kağan adayı arasındaki anlaşmazlığın tahtın ilk varisinin nesebinden kaynaklanmasıdır. Benzer bir sorun Göktürk kağanı Taspar'ın ölümünden sonra onun oğlu Anluo ve yeğeni Daluobian arasında yaşanmış, meclis son olarak Taspar'ın bir başka yeğeni Işbara'yı sahip olduğu vasıflardan dolayı kağan seçmiştir (Erkoç, 2016: 49-50; Taşağıl, 2003: 150).

Bozkır geleneğinde hanedan içerisindeki en büyük üyenin tahta geçme ilkesi bulunduğunu söyleyenler olduğu gibi ancak hükümdarın büyük oğlunun bu hakka sahip olduğunu iddia edenler de vardır (İnalcık, 1959: 69). Yukarıdaki Hun, Göktürk ve Moğol örnekleri ekberiyet ilkesinin tahtın verasetinde tek belirleyici olmadığını göstermektedir. Hükümdarın ölümünden sonra tahtın ilk adayı büyük oğul olmakla birlikte onun ülke yönetmek için yaş, nesep vb. yönlerden ehliyetli olmadığ konusunda kanaat oluşursa sorunun çözümünde meclis kararına başvurulduğu ya da hükümdarın oğlu ve hanedanın diğer adayının bu ihtilafı savaş yoluyla sonlandırdığı anlaşılmaktadır.

\section{4. Çok Eşlilik ve Levirat Evliliği}

Hem müttefik boylarla hem de Çin hanedanlarıyla kurumsallaşmış bir akrabalık diplomasisi sürdüren Hunlarda çok eşlilik (polygamy) kaynaklarda 
daha çok çanyülerin siyasî tercihi olarak betimlense de belirli durumlarda alt sosyal gruplarda da bu evlilik türünün uygulandığına işaret eden bilgiler bulunmaktadır. Bununla birlikte levirat alt sosyal sınıflarda üst sınıflarda olduğu kadar popüler ve yaygın bir olgu değildir (Xie, 1969: 695, 697, 704). Bu bağlamda özellikle üvey anneyle ya da erkek kardeşin eşiyle yapılan levirat evliliklerinin ve çanyülerin siyasî amaçli gerçekleştirdiği siyasî evliliklerin Hunlardaki çok eşliliğin temelini oluşturduğu söylenebilir.

Hunlardaki levirat geleneğiyle ilgili ilk bilgiler Sima Qian'in Shiji adlı tarih kitabına dayanmaktadır. Bu kitapta Hun çanyüsüne sığınan Çinli saray görevlisi Zhonghang Yue ile Hun başkentini ziyarete gelen Han elçisi arasında geçen diyalog dikkat çekicidir:

5. 漢使曰:「匈奴父子乃同穹盧而臥。父死, 妻其後母; 兄弟死, 盡取其妻妻之...。」 中行說曰：...「父子兄弟死, 取其妻妻之, 惡種姓之失也。故匈奴雖亂, 必立宗種。 今中國雖詳不取其父兄之妻, 親屬益疏則相殺, 至乃易姓 ...

\begin{abstract}
Han elçisi şöyle dedi: Hunlarda baba ve oğul aynı çadırda kalır. Babaları öldüğünde üvey annelerini, kardeşleri öldüğünde onun karılarını kendi karıları yaparlar. Zhonghang Yue şöyle söyledi: Baba veya ağabeyleri öldüğünde onların karılarıyla evlenmelerinin nedeni soylarının kaybolmasından korkmalarıdır. Bu nedenle Hunlar düzensiz yaşasalar bile soylarını korumak zorundadırlar. Bugün Çin'de sözde oğul ve kardeşler ölen baba ve kardeşlerinin karılarıyla evlenmezler, ama akrabalık ilişkileri zayıftır, hatta soyadları değiştirilinceye kadar birbirini öldürmeye çalışırlar (Shiji 110.3505).
\end{abstract}

$\mathrm{Bu}$ kayda göre levirat uygulamasının en temel gerekçesi ölen kişinin soyunu kardeş veya oğul vasıtasıyla sürdürme gerekliliğidir. Ölen bir akrabanın karısını ve çocuklarını kabul etmek o kişinin hatırasına karşı bir tür saygı göstergesi olduğu gibi (Xie, 1969: 698) ailenin devamlılı̆̆ını sağlamanın da bir gereğidir. Nitekim bozkır göçebe geleneğinde ölen kardeşin çocukları sadece babalarının değil, mensup oldukları geniş ailenin de soyunu sürdürmektedir. Geleneksel Türk ve Moğol akrabalık terminolojilerinde yeğen (erkek kardeşinin oğlu) ile torunun (oğlunun oğlu) ortak akrabalık terimleriyle işaretlenmesi de (Eski Türkçe atı, Orta Moğolca açi) (Clauson, 1972: 40; Lessing, 1960: 8) bu geleneğin dil kodları olarak değerlendirilebilir.

Hazanov (1975: 81-82) levirat geleneğinin Avrasya göçebeleri arasında binlerce yıldır kalııı ve uzun süreli olmasını üç gerekçeye dayandırmaktadır: 1) Kadın değerli bir mülk olarak kabul edilir ve kocasının ölümünden sonra diğer mülklerle birlikte aileye miras kalır. 2) Levirat dul kadının bakmak zorunda 
olduğu küçük çocukların bakımını ve yetiştirilmesini sağlar. 3) Levirat ölen kişinin soyunun en yakın akrabaları tarafından sürdürülmesinin bir yolu olarak görülür.

Siyasî ilişkiler bağlamında ise levirat evliliği kadın üyeleri soy içinde tutarak kayın boylarla veya diğer ülkelerle var olan ittifakı sürekli kılmaktadır. Hunların yanı sıra onların çağdaşı ve ardılı olan göçebe toplumlarında yaygın bir uygulama olan levirat (Lin, 1986: 178) yalnızca göçebeler arası ilişkilerle sınırlı kalmamış, heqin siyaseti kapsamında Hun çanyüleriyle (ve diğer bozkır hükümdarlarıyla) evlendirilen Çinli prensesler de kocaları öldükten sonra eşlerinin erkek akrabalarıyla evlenmişlerdir. Örneğin, Sui Hanedanı prensesi Yicheng heqin anlaşması gereği evlendiği Göktürk Kağanı Qimin'in ölümünden sonra sırasıyla üç üvey oğluyla da levirat evliliği yapmıştır (Lin, 1986: 179). Bu tür evlilikler Çin geleneklerince hoş karşılanmamasına rağmen (Shiji 110.3505) Çinli prenseslerin üvey oğulları veya kayınları ile evlenmesi aşağıdaki kayıtlardan da anlaşıldığı üzere siyaset gereği Çin imparatorlarınca bizzat teşvik edilmiştir:

6. a. 呼韩邪死, 其前阏氏子代立, 欲妻之, 昭君上书求归, 成帝赦令从胡俗, 遂复为 后单于阏氏焉。遂復為後單于䦚氏焉

Huhanye ölünce daha önceki hatunun oğlu (çanyü) seçildi, (yeni çanyü) onu eş olarak almak istedi, [bunun üzerine] Zhaojun [Han imparatoruna] eve geri dönmeyi talep eden bir mektup yazdı, ancak imparator Hu (Hun) geleneğini sürdürme emri verdi ve sonuçta çanyünün yanzhisi oldu (Hou Hanshu 89.2941).

b. 昆莫年老, 欲使其孫岑陬尚公主。公主不聽, 上書言狀, 天子報曰: 「從其國俗, 欲與烏孫共滅胡。」岑陬遂妻公主

[Wusun kralı] Kunmo yaşlıydı ve torunu Cenzuo'yu [kendi eşi olan] prensesle evlendirmek istedi. Prenses bunu kabul etmedi ve (Han imparatoruna) bir mektup yazd. İmparator şöyle cevap verdi: "Onların geleneklerine göre davranmalısın, Wusunlarla iş birliği yaparak Huları (Xiongnuları) yok etmek istiyorum.” (Böylece) prenses Cenzuo'nun eşi oldu (Hanshu 96B.3904).

Göçebe halklar arasında levirat geleneğinin uygulanışı ekonomik duruma veya sosyal statüye bağlı olarak değişiklik gösterebilmektedir. Çingis Kağan'ın annesi Höelün'ün yoksulluk nedeniyle veya kişisel tercihiyle levirat evliliği yapmamış olması (Broadbridge, 2018: 53) bu duruma örnektir. Zengin ailelerde, özellikle kıdemli eşler sahip oldukları varlıklarla kendi ve çocuklarının geçimini sağlayabildikleri için levirat geleneğine direnebilmektedir (Birge, 1995: 115). Baş eşler ise ekonomik güçlerinin yanı sıra siyasî olarak da ayrıcalıklı bir konumdadırlar. Nitekim Bilge Kağan'ın ölümünden sonra eşi Pofu'nun 


\section{J(ब)}

evlendiğine dair bir bilgi olmadığı gibi Çin kaynakları onun baş eşlik unvanıyla halkına liderlik etmeye devam ettiğini kaydetmektedir.

7. 毘伽可汗妻骨咄祿婆匐可敦率眾自歸, 天子御花蔞樓宴群臣, 賦詩美其事, 封可 敦為賓國夫人, 歲給粉直二十萬

Bilge Kağan'ın hatunu Kutlug Pofu, halkının başında Çin'e sı̆̆ındı. İmparator, Huawo köşkünde ona ve maiyetine ziyafet düzenleyip şiir okudu ve hatuna Pinguo furen Konuk Ülkenin Hanımı unvanı ile iki yüz bin ölçek darı verdi (Xin Tangshu 215b.6055).

\section{Sonuç}

Hun siyasî sistemi İç Asya göçebe toplumunun aile örgütlenmesini model almıştır. Bu aile yapısında büyük amcanın babadan daha kıdemli, küçük amcanın ağabey ile eş sayıldığı geleneksel Türk ve Moğol akrabalık sistemi hâkimdir. Hun yönetim hiyerarşisi en içeride bu geniş ailenin yer aldığı, dışa doğru büyüyen soy grubundan oluşmuştur. Hun toplumunun tüm katmanları benzer biçimde soy gruplarına ayrıldığı için merkezî yönetimin etki alanı başkentten uzaklaştıkça azalmıştır. Yönetici boyun diğer boylar üzerindeki siyasî nüfuzunu pekiştirmek için ise akrabalık diplomasisine başvurulmuştur. Böylece Hun yönetici soyu (Luandi) ile başka boylar arasında ittifak evlilikleri kurulmuştur. Bu da devlet hiyerarşisi genişledikçe soya dayalı akrabalıktan evliliğe dayalı akrabalığa doğru genişleme ihtiyacının ortaya çıkmasıyla açıklanmaktadır.

Hun hükümdarının farklı soy gruplarından kadınlarla yaptığı evlilikler kayın boylar ve hükümdar eşleri arasında da bir hiyerarşi düzeninin oluşmasına neden olmuştur. İktidar mücadelelerine neden olan olağanüstü durumlar (savaş, kıtlık vb.) dışında bu hiyerarşiye çoğunlukla bağlı kalınmıştır. Hunların ardılı olan Göktürk ve Moğol kağanlıklarında yönetim sisteminin olduğu gibi korunmuş olması, akrabalık sistemlerinde görülen farklılıkların terminolojik düzeyde kalması soy ve evlilik esaslı Hun siyasî sisteminin İç Asya'daki göçebe toplumları için kurumsallaşmış olduğunu ortaya koymaktadır.

\section{Özel Adlar ve Terimler}

$\begin{array}{ll}\text { Anluo } & \text { Çince 庵邏 } \\ \text { Aşide } & \text { Çince 阿史德 } \\ \text { Aşina } & \text { Çince 阿史那 } \\ \text { Baideng } & \text { Çince 白登 }\end{array}$




\section{J(ఠ)}

\begin{tabular}{|c|c|}
\hline Bilge (Kağan) & Çince 毗伽 \\
\hline Borcigin & Moğolca Боржигин \\
\hline Börte & Moğolca Бөртэ \\
\hline Çagaday & Moğolca Цагадаŭ \\
\hline Cüçi & Moğolca зүчu \\
\hline Daluobian & Çince 大邏便 \\
\hline Er & Çince 兒 \\
\hline heqin & Çince 和親 \\
\hline Höelün & Moğolca Өэлүн \\
\hline Hongirad & Moğolca Хонгирад \\
\hline Hulugu & Çince 狐鹿姑 \\
\hline Huyan & Çince 呼衍 \\
\hline Huyandi & Çince 壳衍鞮 \\
\hline Işbara & Çince 沙缽略 \\
\hline İssik & Çince 乙息记 \\
\hline Kapgan & Çince 默啜 Mòchuò ya da 遷善 Qiānshàn \\
\hline Lan & Çince 蘭 \\
\hline Laoshang & Çince 老上 \\
\hline Liu Yuan & Çince 劉淵 \\
\hline liujiao & Çince 六角 \\
\hline Luandi & Çince 攣鞮 \\
\hline Modu & Çince 冒頓 \\
\hline Mukan & Çince 木桿 \\
\hline Ögedey & Moğolca Өгəдэŭ \\
\hline Pofu & Çince 婆匐 \\
\hline Qiedihou & Çince 且鞮侯 \\
\hline sijiao & Çince 四角 \\
\hline Taspar & Çince 佗缽 \\
\hline
\end{tabular}




\section{ग(৫)}

$\begin{array}{ll}\text { Touman } & \text { Çince 頭曼 } \\ \text { Wuwei } & \text { Çince 烏維 } \\ \text { Xiwei } & \text { Çince 西魏 } \\ \text { Xubu } & \text { Çince 須卜 } \\ \text { Xulianti } & \text { Çince 虛連題 } \\ \text { Xulihu } & \text { Çince 呴犁湖 } \\ \text { Xulüquanqu } & \text { Çince 虛閭權渠 } \\ \text { Yaglakar } & \text { Çince 藥羅葛 } \\ \text { yanzhi } & \text { Çince 闕氏 } \\ \text { Yicheng } & \text { Çince 義成 } \\ \text { Yizhixie } & \text { Çince 伊稚斜 } \\ \text { Yueji } & \text { Çince 月氏 } \\ \text { Zhonghang Yue } & \text { Çince 中行說 }\end{array}$

\section{Kaynakça}

Ban, Gu 班固. (1962). 漢書 [Han Kitab1]. Beijing: Zhonghua shuju.

Birge, B. (1995). Levirate Marriage and the Revival of Widow Chastity in Yüan China. Asia Major, 8(2), 107-146.

Broadbridge, A. F. (2018). Women and the Making of the Mongol Empire. Cambridge: Cambridge University Press.

Clauson, Sir G. (1972). An Etymological Dictionary of Pre-Thirteenth Century Turkish. Oxford: Oxford University Press.

Durrant, S. et al. (2016). Zuo Tradition/Zuozhuan: Commentary on the "Spring and Autumn Annals". Seattle \& London: University of Washington Press.

Dziebel, G. V. (2007). The Genius of Kinship: The Phenomenon of Human Kinship and the Global Diversity of Kinship Terminologies. New York: Cambria Press.

Ecsedy, H. (1972). Tribe and Tribal Society in the 6th Century Turk Empire. Acta Orientalia Academiae Scientiarum Hungaricae, 25, 245-262.

Erkoç, H. İ. (2016). Batı Göktürk Kağanlığ'nın Kuruluşu. Hacettepe Üniversitesi Edebiyat Fakültesi Dergisi, 33(1), 43-72. 
Erkoç, H. İ. (2019). Göktürk Boylarının Tespit Edilmesinde Çin ve Tibet Kaynaklarının Önemi. Alpargu, M. et al. (Eds.), Genel Türk Tarihi Kaynakları: Ordu Çalıştayı Bildirileri (pp. 77-160). Ordu: Kültür Yayınları.

Fan, Ye 范曄. (1973). 後漢書 [Sonraki Han Kitab1]. Beijing: Zhonghua shuju.

Fang, Xuanling 房玄齡. (1974). 晉書 [Jin Kitab1]. Beijing: Zhonghua shuju.

Harmatta, J. (1952). The Dissolution of the Hun Empire. Acta Archaeologica, 2(4), 277-304.

Hazanov, A. M. (1975). Sotsial'naya istoriya skifov. Moskva: Nauka.

İnalcık, H. (1959). Osmanlılar'da Saltanat Veraseti Usulü ve Türk Hâkimiyet Telakkisiyle İlgili. Ankara Üniversitesi SBF Dergisi, 14(1), 69-94.

Kim, H. J. (2017). The political organization of Steppe empires and their contribution to Eurasian interconnectivity: the case of the Huns and their impact on the Frankish West. Kim, H. J. et al. (Eds.), Eurasian Empires in Antiquity and the Early Middle Ages Contact and Exchange between the Graeco-Roman World, Inner Asia and China içinde (pp. 15-33). Cambridge: Cambridge University Press.

Kradin, N. N. (2011). Stateless Empire: The Structure of the Xiongnu Nomadic Super-Complex Chiefdom. Brosseder, U. \& Miller, B. K. (Eds.), Xiongnu Archaeology: Multidisciplinary Perspectives of the First Steppe Empire in Inner Asia içinde (pp. 77-96). Bonn: Vor- und Frühgeschichtliche Archäologie, Rheinische Friedrich-Wilhelms-Universität Bonn.

Lessing, F. D. (1960). Mongolian-English Dictionary. Bloomington-Indiana: The Mongolia Society.

Liao, Yang 廖杨. (2004). 匈奴宗法文化论 [Xiongnuların Ataerkil Kültürü Üzerine]. Journal of Inner Mongolia University (Humanities and Social Sciences), 36(1), 17-20.

Lin, Gan 林幹. (1986). 匈奴通史 [Xiongnu Genel Tarihi]. Beijing: Renmin chuban she.

Lindholm, C. (1986). Kinship Structure and Political Authority: The Middle East and Central Asia. Comparative Studies in Society and History, 28(2), 334-355.

Linghu, Defen 令狐 德荣. (1971). 周書 [Zhou Kitab1]. Beijing: Zhonghua shuju.

Liu, Xu 劉㽛. (1975). 舊唐書 [Eski Tang Kitab1]. Beijing: Zhonghua shuju.

Lkhagvasuren, G. vd. (2016). Molecular Genealogy of a Mongol Queen's Family and Her Possible Kinship with Genghis Khan. PLOS ONE, 11, 1-31. 


\section{J(ఠ)}

Mary, L. vd. (2019). Genetic Kinship and Admixture in Iron Age Scytho-Siberians. Human Genetics, 138(4), 411-423.

Miller, B. K. (2014). Hun "Kings" and the Political Order of the Steppe Empire. Journal of the Economic and Social History of the Orient, 57(1), 1-43.

Onon, U. (2001). The Secret History of the Mongols: The Life and Times of Chinggis Khan. London, New York: Routledge.

Ouyang, Xiu 歐陽修. (1975). 新唐書 [Yeni Tang Kitab1] Beijing: Zhonghua shuju.

Ögel, B. (1982). Türklerde Devlet Anlayışı (13. Yüzyılın Sonlarına Kadar). Ankara: Başbakanlık Basımevi.

Scheffler, H. W. (1980). Kalmuk Mongol Kin Classification. Anthropological Linguistics, 22(6), 233-247.

Sima, Qian 司馬遷. (2014). 史記 [Tarihçinin Kayıtlar1]. Beijing: Zhonghua shuju.

Taskin, V. S. (1973). Materialy po istorii syunnu (po kitayskim istoçnikam). Vvedeniye, perevod i kommentarii V. S. Taskina (2). Moskva: Nauka.

Taşağıl, A. (2003). Göktürkler I. Ankara: Türk Tarih Kurumu.

Taşbaş, E. (2019). The Turkic Kinship System. Acta Orientalia Academiae Scientiarum Hungaricae, 72(2), 245-258.

Tekin, T. (1998). Orhon Yazıtlarl: Kül Tigin, Bilge Kağan, Tunyukuk. İstanbul: Simurg.

Tishin, V. V. (2019). A Study of the Ancient Turks Family. Social Evolution \& History, $18(2), 115-132$.

Xie, Jian 謝劍. (1969). 匈奴社會組織的初步研究（氏族、婚姻、和家族的分析） [Xiongnu Sosyal Organizasyonu Üzerine Ön Çalışma (Soy, Evlilik ve Aile Analizi)]. Bulletin of the Institute of History and Philology, Academia Sinica, 40, 669-720. 